\title{
ФЕНОМЕН ГРИ В КОНТЕКСТІ ПОСТМОДЕРНІСТСЬКОї ФІЛОСОФСЬКОї ПАРАДИГМИ
}

\section{М.О. Чулошнікова}

В наших попередніх роботах ([10], [11]) ми з'ясовували зміст, сутність та відмінність різних історичних концепцій гри, можливості їі структурування та ресурси функціювання в різних галузях науки та людської діяльності, а також накреслили декілька підходів до їі класифікації. У цій статті ми ставимо за мету дослідити інший важливий аспект означеного феномену: можливість та доречність використання, а можливо, й активного впровадження гри в практику філософського міркування в якості основного «інструментарію» та основного принципу розуміння світу.

Аналізуючи розмаїття гри в різних історичних епохах розвитку людства, не можна не помітити тенденцію до ㄲï звеличування, підвищення статусу в процесі розбудови філософського пізнання. Людина, досліджуючи зазначений феномен, начебто захоплюється його глибинністю, багатофункціональністю, всюдисутністю, та, затамувавши подих, дедалі вище підіймає її в ієрархії цінностей.

Початок створення перших лудологічних парадигм сягає часів Античності, нерозривно пов'язаний з філософськими та теологічними пошуками тогочасних мислителів (Платон, Геракліт). В царині філософського міркування античності феномен гри посідає чільне місце: постулюється як спосіб життя, згодом набуваючи онтологічного статусу (що було зроблено вперше).

Середньовіччя та Ренесанс надають грі також величного - деміургічного статусу, розуміючи їі як певну модель буття (Іван Дамаскін,

Актуальні проблеми духовності 
Іван Єріугена, Ніколас Кузанський, Марсіліо Фічіно). До лудологічної концепції в цей час залучається мотив щодо провідної ролі гри в реалізації особистості: гра постає як визначальна характеристика творчої суб'єктивності особистості.

Поміркованість та раціональність філософської думки в період німецької класичної філософії робить наголос на прикладному, інструментальному характері гри: поняття та категорії, пов'язані з лудологічною парадигмою, постулюються як допоміжний понятійний інструментарій в окремих філософських дослідженнях, - зокрема, в межах естетичних концепцій (Кант, Шіллер).

Саме така строкатість та різновекторність досліджень феномену гри (філософія, культурологія, психологія, педагогіка),- спричиняє виникнення лудологічної концепції Й. Хейзінги [9], аналіз якої було проведено в наших попередніх роботах. До зазначеного раніше варто додати, що Й. Хейзінга по-перше, частково відтворює попередні світоглядні традиції, по-друге, надає нового забарвлення лудологічним дослідженням: не тільки поширює психологічний («гра - це вільна діяльність»), та культурологічний («гра старша за культуру») аспекти, але й проголошує нові- аксіологічний («гра перебуває поза межами «добро - зло») та телеологічний (гра за своєю сутністю не призначена для задоволення будь - яких потреб, їі ціль - в ній самій). Також Й. Хейзінга підкреслив, що більшість дослідників гри залишають поза дужками або недооцінюють той факт, що гра переважно розташовується «на території естетичного», і головне в ній - «естетичний зміст».

Проте, найбільшої популярності, за одностайним твердженням багатьох дослідників, лудологія як парадигма світобачення та світорозуміння набуває в період постмодернізму. Подібна увага, що майже межує з модою, зумовлена особливостями постмодернізму.

Ще Кант, визнаючи за грою статус гармонійної основи всіх пізнавальних властивостей людини та особливим «оживляючим чинником душ», підкреслює при цьому, що ступінь залученості гри до процесу дослідження має певну межу (вона - всього лише корелят суб'єктивності).

Проте, обережні застереження «витонченого філософа» не стали в нагоді новому постіндустріальному суспільству та його теоретикам постмодерністам. Разом з завзятим прагненням замінити традиційне буржуазне індустріальне суспільство - зопалу замінюються, дискредитуються та піддаються деконструкції колишні економічні та політичні цінності - влада, гроші, обмін, виробництво; замість скинутих проголошується новітня цінність - інформація - як найцінніша цін- 
ність та найпопитовіший товар.

Найбільш поширеною точкою зору є твердження, що своїм народженням постмодернізм повинен завдячувати низці літературних творів, що вийшли наприкінці 30-х років минулого сторіччя («Помин по Фіннегану» Дж. Джойс, «Гра в бісер» Г. Гессе, «Майстер та Маргарита» М.Булгаков, «Доктор Фаустус» Томас Манн) (Див.: [2], [4]).

Названі твори ознаменували кризу класичного модернізму (і не тільки в галузі літератури), долали його серйозний трагізм (притаманний, наприклад, творам Кафки) за допомогою грайливої іронії, жартівливого глузування над непереборними проблемами недосконалої людини в недосконалому світі (іноді - зіпсованої людини в сплюндрованому нею ж світі). Болісне відчуття неможливості та небезпечності співіснування Людини і Світу «знеболювалося» саме за рахунок абсолютизації ігрового принципу світобачення та світорозуміння.

Аналізуючи сутність тлумачення та розвитку лудологічної концепції в означений період, не можна не приділити певної уваги самому процесу його формування, чинникам становлення та розвитку. Вперше постмодернізм став філософським поняттям після виходу в світ та широкого обговорення книги французського філософа Жан-Франсуа Ліотара «Постмодерністська доля», в якій він критикував поняття мети оповіді, або мети історії, тобто влади єдиної розповідної стратегії, парадигми - наукової, філософської або художньої. Для представників постмодерністської філософії виявляються неприйнятними ті форми філософського знання, які претендують на універсалізм, володіння абсолютною істиною. Підхоплюючи гасло нігілізму, проголошене Ф. Ніцше [7, с. 269], вони розгортають, за висловом Ліотара, «війну цілому»; актуальним та сучасним - скасування «догматизму» класичного мислення, протиставляючи йому «багатомірний спосіб філософствування», оснований на ігрових, деконструктивістських, плюралістичних принципах (Цит. по: [4, с. 92]).

Являючись безпосереднім наступником модернізму та постструктуралізму, постмодернізм стає також їх спадкоємцем, привласнюючи в якості філософського методу деконструкцію. В нагоді стає гра...

Проголошена Деррідою ідея деконструкції [5, с. 204] відразу ж стала одним з основних принципів постмодернізму. Для французського мислителя вона являлась головним засобом перетворення філософії в так звану «постфілософію». Згідно з позицією Дерріди, деконструкція - це мисленнева операція, що застосовується до традиційної структури фундаментальних категорій західноєвропейської онтології. Вона висловлює нігілістичну, іноді - іронічно - недовірливу та реляти- 
вістську по своїй суті ідею штучного розкладання цілого на частини, свого роду «інтелектуального демонтажу», «розбирання» систематичних філософських концепцій, яка необхідна начебто для того, щоб зрозуміти, як ці концепції було сконструйовано. В цій, на перший погляд, безневинній процедурі, (особливо притаманній, як відомо, дитячій свідомості), міститься справжня душа постмодернізму, який прагне дискредитувати класичну культуру та філософію. Вважаючи, що логоцентризм придушує плюралістичні та ірраціоналістичні начала пізнавального процесу, французький філософ здійснює спробу звільнити сучасну філософію від класичної моделі раціональності. Свою теорію деконструкції Дерріда прагне звести до наступних положень:

1. Деконструкція - це, перш за все, нігілістичний досвід десубстанціалізації буття та знищення підгрунтя (підстав) класичної онтології;

2. Деконструкція симулює пізнавальний процес, видає об'ективну істину тільки за видимість (симулякр) всезагального логічного першопочатку;

3. Деконструкція висловлює ігрове ставлення до тексту, який є єдино можливим предметом філософської думки (світ як текст!) та відповідної науки про нього - граматології.

Дерріда вважає, що логічна необгрунтованість людського існування, відсутність твердого змістовного фундаменту, на який можна «впасти та розбитися», роблять деконструктивістську практику простою, «безпечною» та інтелектуально безвідповідальною. Отже, боротьба $з$ логосом (логомахія!) і утворює вищу та кінцеву мету постмодерністської філософії.

В постмодернізмі панує всезагальне змішання та глузливість над усім, одним з його головних принципів стала «культурна опосередкованість», або, якщо говорити стисло, цитата. «Ми живемо в епоху, коли всі слова вже сказано», якось проголосив Аверінцев [1, с.63]; тому кожне слово, навіть кожна буква в постмодерністській культурі це цитата.

Піддаючи різкій критиці саму ідею бінарних опозицій як таку, постмодернізм уявляє себе поза межами протиставлень суб'екта та об'екта, чоловічого та жіночого, внутрішнього та зовнішнього, центру та периферії, сакрального та профанного. Підставою для таких «аксіологічних кульбітів» стає те, що грі традиційно та вже на цей час незапе- 
речно приписується принципово непродуктивний та позараціональний характер.

По-перше, ігрова сутність постмодернізму полягає в прагненні (i здатності!) деонтологізувати пізнавальний процес за рахунок використання деконструювання, в ігровій профанації цінностей, в знятті сутнісних антиномій культури через сміх, в ствердженні релятивності пізнавальних пріоритетів , в поліфонії та внутрішньому діалогізмі формо-змістових ходів філософського міркування.

Характерним прикладом ігрової та антиреалістичної сутності постмодерна є категорія симулякра (від лат. simulacrum-зображення, подоба, видимість). Вперше використана в роботах Бодріяра, ця категорія відразу ж займає одне з ключових місць в структурі постмодерністського дискурса. В самому загальному розумінні, симулякр є універсальною симуляцією пізнання та буття, «удаваність», за якоюхаос та беззмістовність порожнечі. За словами Бодрійяра (див.: [4, c. 103]), постмодерністська епоха характеризується тотальною симуляцією практично в усіх галузях людського буття. Саме в цьому й проявилась симулятивістська природа постмодерністського розуму, який тільки робить вигляд (тобто симулює), що пізнає «безмежно багатоманітну» дійсність, проте насправді грає сам із собою. Симулякр породжує «гіперреальність», про яку так полюбляють говорити постмодерністи. В ній вони вбачають той самий символ віртуальної та плюралістичної істини, яка, за словами Дерріди, суть «можливість не-істини», представленої в симулякрах. Саме симулякр є вищим символом тої нігілістичної та механістичної думки, яку породила новоєвропейська культура в XVII-XVIII ст. Культура втратила свій творчий характер, припинила створювати нові цінності та принизилась до рівня еклектичного (тобто, по суті, деструктивного) відтворення вже існуючого.

Та це не дивно, оскільки тенденція деонтологізації філософії, що намітилася ще в новоєвропейській науці, безумовно мала б призвести до меонічної (від давньогроецьк. meоn - небуття, не - суще) та ілюзіоністської культури. В якості істинного буття було прийнято абсолютне небуття, ніщо, тобто меон. Справжнє перетворилось на те, що не є сущим, (не-сущим), істина перетворилась на хибу. Являючись закономірним наслідком націоналістських та нігілістичних тенденцій новоєвропейської думки, меонізм виступив в якості світоглядної основи не тільки ігрових, але й деконструктивістських начал постмодерністської філософіï.

На думку Бичкова [3, с. 453], псевдо-дитяча безпосередність такого підходу і є та сама простота, що є гіршою за крадіжку. Адже в да- 
ному випадку мається на увазі не аналіз або інтерпретація системи філософських категорій, a їх повне змістове знищення. Завдяки таким «інтелектуальним розбиранням» думка розсіюється, деонтологізується, перетворюється на порожню абстракцію. Руйнується змістова структурованість світу. Тотальна «децентралізація» пізнання та буття призводить до того, що в постмодернізмі філософія як цілісний та інтегральний світогляд перестає бути філософією. Прийнявши, за словами Дерріди, «піднесене» им'я постфілософії, вона оголошує нищівну війну логоценричній традиції християнської філософії та культури.

Іншим фундаментальним принципом постмодернізму є відмова від істини. Різні філософські напрямки по-різному розуміли істину, проте, постмодернізм взагалі відмовляється вирішувати та визнавати цю проблему - хіба що як проблему мовної гри в дусі пізнього Вітгенштейна, - мовляв, істина - це просто слово, яке не має іншого змісту окрім того, що означає за словником. Важливішим при цьому є не значення цього слова, а зміст, його етимологія, те, як воно вживалось раніше. «Іншими словами, - пише П'ятигорський, повністю погоджуючись з Витгенштейном, що «істина»-це слово, яке не має іншого смислу, ніж той, що це слово означає, та рішуче не погоджуючись 3 марксизмом, який стверджує, що істина є історичною, постмодерністи вбачають ㄲï (істину) тільки як слово, як елемент тексту, як, врешті решт, сам текст» $[8$, с. 164$]$.

Наступною особливістю постмодернізму стала відмова від серйозності та всезагальний плюралізм.

Інтерпретуючи слова Умберто Еко, італійського семіотика та автора постмодерністського бестселера «Ім'я рози», російський філософ та культуролог Олександр П'ятигорський в своєму есе про постмодернізм зазначає: «Умбетро Еко пише, що в сучасності постмодерніст відчайдушно намагається порозумітися, пояснюючи себе іншому - другу, ворогу, світові, - кому завгодно, бо ж він помре в той момент, коли нема кому буде пояснювати. Проте, пояснюючи іншому себе, він намагається це також зробити як інший, а не як він сам» [8, с. 122]. Саме такий тип порозуміння і $\epsilon$, з нашого погляду одним з ігрових «механізмів», що являє собою Повторювання, Грайливість та Почерговість, змінність позицій та перетворень - основу ігрових стосунків.

За одностайною думкою дослідників постмодернізму, він був першим (і останнім) напрямком XX ст., який відкрито зізнавався в тому, що текст не відображує реальності, а творить нову реальність, скоріш за все, декілька реальностей, часто таких, що зовсім не залежать одна від одної. Адже будь-яка історія, у відповідності з розумінням 
постмодернізму, - це історія створення та інтерпретації тексту. Звідки ж тоді взятися реальності? Реальності просто немає. Якщо завгодно, $\epsilon$ різноманітні віртуальні реальності - недарма постмодернізм розквітнув в епоху персональних комп'ютерів, масового відео, Інтернету, за допомогою якого зараз не тільки листуються та проводять наукові конференції, але й займаються віртуальним коханням.

Оскільки реальності більше немає, постмодернізм тим самим зруйновує найголовнішу опозицію класичного модернізму - неоміфологічну опозицію між текстом та реальністю, робить непотрібним пошук (як правило, болісний!) меж між ними. Тепер пошук припинено: реальність остаточно не виявлено, мається в наявності тільки «гіперреальність», відверто кажучи - релятивістська фікція...

Дослідник постмодернізму І.Ільїн зазначає: «Постмодерністська думка прийшла до висновку, що все, що маємо за дійсність, насправді не що інше, ніж уява про неї, яка залежить до того ж від кута зору, який обирає спостерігач та зміна якого призводить до кардинальної зміни самої уяви» [6, с. 33]. Таким чином, сприйняття людини проголошується приреченим на «мультиперспективізм», на постійну й калейдоскопічно мінливу низку ракурсів дійсності, що не дозволяють в своєму маячінні пізнати сутність.

3 вищезазначеного видно, що теоретична своєрідність постмодерністської філософії визначається її прагненням зруйнувати, деконструювати класичну онтологію та гносеологію, профанувати західноєвропейський раціоналізм, а лудологічна концепція в контексті її тлумачення в рамках саме цього періоду дискредитується. Отже, практика абсолютизації ігрового принципу в період постмодернізму як основного принципу перетворення філософії на «постфілософію» має визнаватися невиправданою.

\section{1 Бібліографія}

[1] Аверинцев C.C. Культурология Йохана Хейзинги // Вопросы философии. -1988 . - № 5 .

[2] Бойко П. Игра и деконструкция в постмодернистской философии // КОРФО: СЭНИ «Тоtum» (философский журнал).-2002.№ 1 (http://www.korfo.org/rus/totum/012002//html).

[3] Бычков В.В., Эстетика.- М.: 2002. 
[4] Гречко П.К., Вержбицкий В.В. На рубеже веков: постмодернистская альтернатива в философии $<\mathrm{URL}=\mathrm{http} / /$ www.pfu.edu.ru/ ido/ffec/philos/ph11.html>.

[5] Деррида ЖK. Структура, знак и игра в дискурсе гуманитарніх наук // Письмо и Различие. - М., 2000.

[6] Ильин И. Постструктурализм. Деконструктивизм. Постмодернизм. - М., 1996.

[7] Ницше Ф. Соч. в 2-х т.-М., 1997.- Т. 2.

[8] Пятигорский А.М. О постмодернизме // Пятигорский А.М. Избр. труды. - М., 1996.

[9] Хейзинга Й. Homo ludens. М., "Прогресс", 1992.

[10] Чулошникова M.А. Игра как проявление реальности сознания и специфика субъектно-объектных отношений // Інформенергетика II-го тисячоліття: соціолого-синергетичний та медико-екологічний підходи. Зб. наук. праць другої міжнародної науково-практичної конференції. - Випуск II. Київ-Кривий Ріг. - 2003.

[11] Чулошнікова М.О. Поняття гри в структурі гуманітарного знання // Актуальні проблеми духовності. Зб. наук. праць. - Випуск 6. Кривий Ріг, 2005. 